\title{
ESTABLISHMENT OF VAPOR HYDRATION TEST (VHT) CAPABILITIES AT THE SAVANNAH RIVER TECHNOLOGY CENTER
}

\author{
T.H. Lorier
}

Westinghouse Savannah River Company

Savannah River Technology Center

Aiken, SC 29808

Westinghouse Savannah River Company

Savannah River Technology Center

Aiken, SC 29808

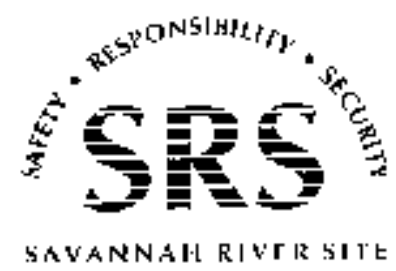

PREPARED FOR THE U.S. DEPARTMENT OF ENERGY UNDER CONTRACT NO. DE-AC09-96SR18500 
This document was prepared in conjunction with work accomplished under Contract No. DE-AC09-96SR18500 with the U. S. Department of Energy.

\section{DISCLAIMER}

This report was prepared as an account of work sponsored by an agency of the United States Government. Neither the United States Government nor any agency thereof, nor any of their employees, makes any warranty, express or implied, or assumes any legal liability or responsibility for the accuracy, completeness, or usefulness of any information, apparatus, product or process disclosed, or represents that its use would not infringe privately owned rights. Reference herein to any specific commercial product, process or service by trade name, trademark, manufacturer, or otherwise does not necessarily constitute or imply its endorsement, recommendation, or favoring by the United States Government or any agency thereof. The views and opinions of authors expressed herein do not necessarily state or reflect those of the United States Government or any agency thereof.

This report has been reproduced directly from the best available copy.

Available for sale to the public, in paper, from: U.S. Department of Commerce, National Technical Information Service, 5285 Port Royal Road, Springfield, VA 22161, phone: (800) 553-6847, fax: (703) 605-6900

email: orders@ntis.fedworld.gov

online ordering: http://www.ntis.gov/help/index.asp

Available electronically at http://www.osti.gov/bridge

Available for a processing fee to U.S. Department of Energy and its contractors, in paper, from: U.S. Department of Energy, Office of Scientific and Technical Information, P.O. Box 62, Oak Ridge, TN 37831-0062,

phone: (865)576-8401,

fax: (865)576-5728

email: $\underline{\text { reports@ adonis.osti.gov }}$ 


\title{
ESTABLISHMENT OF VAPOR HYDRATION TEST (VHT) CAPABILITIES AT THE SRTC
}

\author{
T.H. Lorier
}

\author{
Westinghouse Savannah River Company \\ Savannah River Technology Center \\ Aiken, SC
}

This report was prepared by Westinghouse Savannah River Company (WSRC) for the United States Department of Energy under Contract No. DE-AC09-96SR18500 and is an account of work performed under that contract. 


\begin{tabular}{|c|c|c|c|}
\hline $\begin{array}{l}\text { Task Title: Vapor } \mathrm{Hy} \\
\text { Tests }\end{array}$ & & & \\
\hline $\begin{array}{l}\text { Task Leader: } \\
\text { T.H. Lorier }\end{array}$ & Signature: & $\begin{array}{l}\text { Organization: } \\
\text { ITS }\end{array}$ & Date: \\
\hline $\begin{array}{l}\text { Technical Reviewer: } \\
\text { D.K. Peeler }\end{array}$ & Signature: & $\begin{array}{l}\text { Organization: } \\
\text { ITS } \\
\end{array}$ & Date: \\
\hline $\begin{array}{l}\text { Level } 3 \text { Manager: } \\
\text { E.W. Holtzscheiter }\end{array}$ & "Signature: & $\begin{array}{l}\text { Organization: } \\
\text { ITS }\end{array}$ & Date: \\
\hline $\begin{array}{l}\text { Level } 4 \text { Manager: } \\
\text { S.L. Marra }\end{array}$ & "Signature: & $\begin{array}{l}\text { Organization: } \\
\text { ITS }\end{array}$ & Date: \\
\hline
\end{tabular}


Immobilization Technology Section

Savannah River Technology Center

Westinghouse Savannah River Company

\section{GLOSSARY}

$\begin{array}{ll}\text { AGCR } & \text { Acceptable Glass Composition Region } \\ \text { ASTM } & \text { American Society of Testing and Materials } \\ \text { DIW } & \text { Deionized Water } \\ \text { DOE } & \text { Department of Energy } \\ \text { DWPF } & \text { Defense Waste Processing Facility } \\ \text { HLP } & \text { Hanford LAW Product-Acceptance } \\ \text { HLW } & \text { High Level Waste } \\ \text { IA } & \text { Image Analysis } \\ \text { ITS } & \text { Immobilization Technology Section } \\ \text { LAW } & \text { Low Activity Waste } \\ \text { OM } & \text { Ocular Mic roscope } \\ \text { PCT } & \text { Product Consistency Test } \\ \text { PNNL } & \text { Pacific Northwest National Laboratory } \\ \text { Pt } & \text { Platinum } \\ \text { S } & \text { Surface Area } \\ \text { SEM } & \text { Scanning Electron Microscope } \\ \text { SPFT } & \text { Single Pass Flow Through } \\ \text { SRTC } & \text { Savannah River Technology Center } \\ \text { V } & \text { Volume } \\ \text { VHT } & \text { Vapor Hydration Test } \\ \text { WSRC } & \text { Westinghouse Savannah River Company } \\ \text { XRD } & \text { X-ray Diffraction }\end{array}$


Immobilization Technology Section

Savannah River Technology Center

Westinghouse Savannah River Company

This page intentionally left blank. 
Immobilization Technology Section

Savannah River Technology Center

Westinghouse Savannah River Company

\section{ACKNOWLEDGEMENTS}

The author would like to acknowledge John Vienna, David Peeler, and Kevin Brown for their technical guidance and reviews; Irene Reamer and Phyllis Workman for their patience and hard work; and William Holtzscheiter, Sharon Marra, and Renee Spires for management and guidance. This study was co-funded by the Department of Energy's Office of Science and Technology through the Tanks Focus Area and through the Defense Waste Processing Facility. Westinghouse Savannah River Company is operated for the U.S. Department of Energy under Contract No. DE-AC09-96SR18500. 


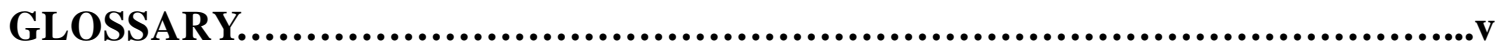

ACKNOWLEDGEMENTS .....................................................vii

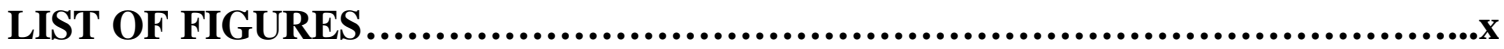

LIST OF TABLES.........................................................................

EXECUTIVE SUMMARY.........................................................xi

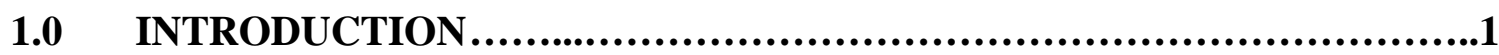

2.0 EXPERIMENTAL............................................................

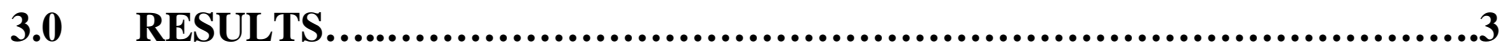

3.1 Alteration Rates .................................................................................

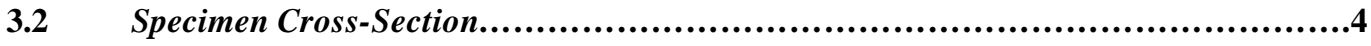

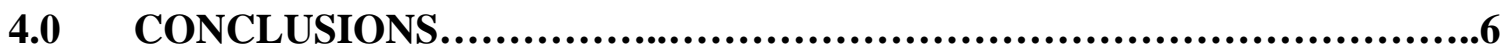

5.0 REFERENCES.............................................................6

APPENDIX 
Immobilization Technology Section

Savannah River Technology Center

Westinghouse Savannah River Company

\section{LIST OF FIGURES}

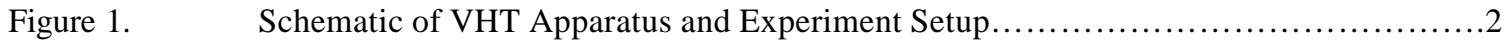

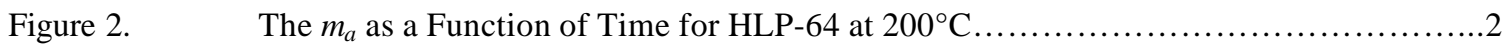

Figure 3. Cross-section of HLP-58 Subjected to VHT at $200^{\circ} \mathrm{C}$ for 26 Days.......................

Figure 4. Cross-section of HLP-60 Subjected to VHT at $200^{\circ} \mathrm{C}$ for 26 Days......................

Figure 5. Cross-section of HLP-68 Subjected to VHT at $200^{\circ} \mathrm{C}$ for 26 Days.....................

Figure 6. Cross-section of HLP-71 Subjected to VHT at $200^{\circ} \mathrm{C}$ for 26 Days....................5

Figure 7. Cross-section of HLP-72 Subjected to VHT at $200^{\circ} \mathrm{C}$ for 26 Days.......................

Figure 8. Cross-section of HLP-74 Subjected to VHT at $200^{\circ} \mathrm{C}$ for 26 Days.....................

\section{LIST OF TABLES}

Table 1.

VHT Alteration Rates at $200^{\circ} \mathrm{C}$

...4

Table A.1.

VHT Responses for VHT Glasses. 


\subsection{INTRODUCTION}

The U.S. Department of Energy (DOE) intends to immobilize the low-activity waste (LAW) at Hanford in the form of borosilicate glass for storage and disposal (DOE, 2000; Vienna et al., 2001). The LAW glass will be disposed of in a shallow land-burial facility (on site), and it must be demonstrated that the disposal system will adequately retain the radionuclides and prevent contamination of the surrounding environment. Waste-form performance dictates the release of contaminants after disposal. It was found that the release of radionuclides from the waste form via interaction/reaction with water is the prime threat to the environment surrounding a disposal site (Mann et al., 2001).

The long-term performance of the LAW glass must be assessed from an effective short-term evaluation methodology. A series of short-term tests and modeling approaches has been identified in an attempt to link glass composition to performance in the disposal facility (Schulz et al., 2000). This testing series includes the Product Consistency Test (PCT-A and PCT-B) and the Vapor Hydration Test (VHT). As currently defined in Hanford Contract DE-AC27-01RV14136, Section C (DOE, 2000), all glasses must pass a PCT-A limit of $2.0 \mathrm{~g} / \mathrm{m}^{2}$ and a VHT limit of $50 \mathrm{~g} /\left(\mathrm{m}^{2} \cdot\right.$ day $)$.

For recent LAW product acceptance testing (Vienna et al., 2000, 2001; Schulz et al., 2000), the PCT was performed at the Savannah River Technology Center (SRTC) and the VHT was performed at the Pacific Northwest National Laboratory (PNNL). Up until September 2002, the SRTC did not have the capabilities of performing the VHT. It was deemed necessary that the SRTC acquire this capability in order to play a role in this realm of durability testing - round robins, various glass testing, etc. This report summarizes the procedure of conducting a VHT and the results of initial testing at the SRTC in order to illustrate that the Westinghouse Savannah River Company (WSRC) now has the capabilities to perform these durability tests.

\subsection{EXPERIMENTAL}

In conducting a VHT, a monolithic specimen is exposed to water vapor at elevated temperatures in a sealed stainless-steel vessel (schematic shown in Figure 1). This environment greatly accelerates the progression of glass corrosion by water and the formation alteration products (Vienna et al., 2001). The procedure covers test temperatures from $5^{\circ} \mathrm{C}$ up to $300^{\circ} \mathrm{C}$, which is the maximum temperature given by the design of stainless steel vessels used to conduct the test. Glass corrosion is affected by both the elevated temperature and the high glass surface area (S) to solution volume (V) ratio achieved. The results of the VHT can be used in conjunction with other tests (e.g., the PCT and the Single Pass Flow Through Test (SPFT)) and modeling to compare the long-term durability behavior of candidate waste forms and to provide useful information to performance assessment. This test is applicable, but not limited to, a variety of consolidated solids including potential waste forms such as glass, ceramics, and glass ceramics.

The VHTs for this study were performed according to technical procedure (procedure ITS-0019, Rev. 0), which is compliant with the proposed American Society for Testing and Materials (ASTM) procedure (the proposed ASTM procedure is based on PNNL procedure \#GDL-VHT). Samples with approximate dimensions of $10.0 \times 10.0 \times 1.5 \mathrm{~mm}$ were prepared from heat-treated glass bars with a diamondimpregnated saw and polisher (procedures ITS-0016, Rev. 0 and ITS-0017, Rev. 0, respectively). All sides were polished to 600-grit surface finishes with silicon carbide paper. The samples, stainless-steel vessels and lids, gaskets, and supports were cleaned, and the each sample was suspended from the stainless-steel support with platinum (Pt) wire. An amount of deionized water (DIW), predetermined as to the size (volume) of the vessel, temperature, and number of samples per vessel, was added to the bottom of the vessel. The vessel was then sealed and held at constant temperature in a convection oven for a preset time, removed, weighed, and quenched in water. 


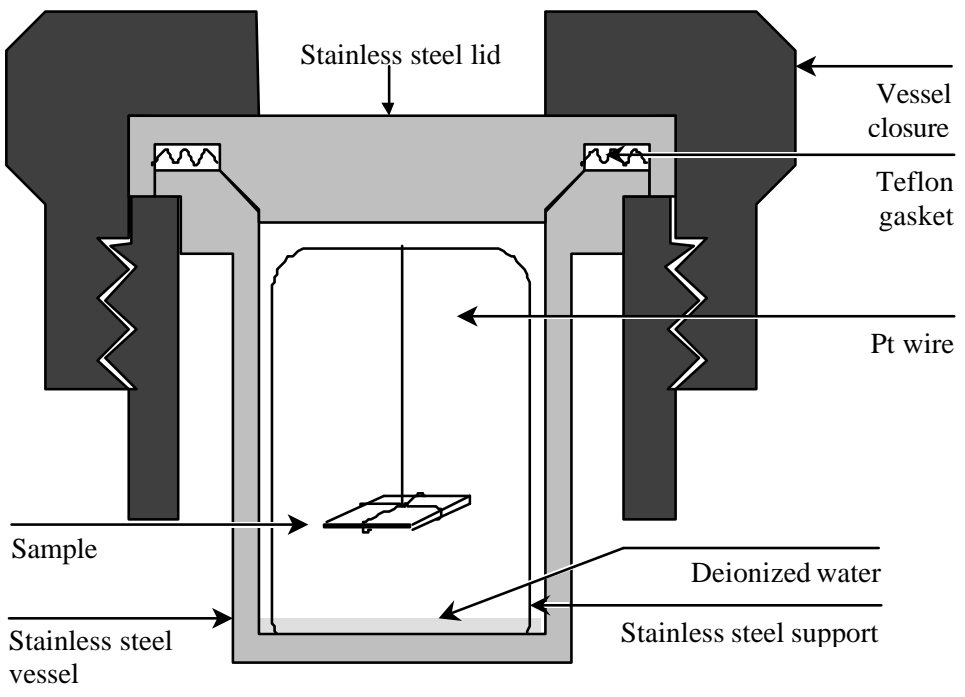

Figure 1. Schematic of VHT Apparatus and Experiment Setup.

After the test termination, specimens were removed from the vessel and divided into two sections with a diamond-impregnated saw. One part was used for image analysis (IA) evaluation with an ocular microscope (OM) of the specimen's cross section. The other part was to be used for alteration phase identification by x-ray diffraction (XRD) and/or scanning-electron microscope (SEM), but could not be performed due to budgetary constraints. All data comparisons performed in this report were based on the remaining glass thickness. The remaining glass thickness was determined by performing at least ten measurements equally distributed across the sectioned specimen. This step yielded the average thickness of the remaining glass.

The initial dimensions of the specimens were measured with calipers, while the thickness of the unaltered glass was measured with the IA system connected to the OM. In order to confirm that both modes of measurement were accurate, both devices were calibrated. The calipers were calibrated at the Standards Lab of the WSRC, and the OM was calibrated with an Olympus micrometric calibration ruler with the resolution of $\leq 0.01 \mathrm{~mm}$.

The mass of glass altered or converted into alteration products $\left(m_{a}\right)$ per unit surface area is calculated with the following formula,

$$
m_{a}=\frac{1}{2} d_{i} \rho\left(1-\frac{d_{r}}{d_{i}}\right)=\frac{m_{i}}{2 w_{i} l_{i}}\left(1-\frac{d_{r}}{d_{i}}\right)
$$

where

$$
\begin{aligned}
d_{i} & =\text { initial glass thickness } \\
\rho & =\text { bulk density } \\
d_{r} & =\text { thickness of remaining glass } \\
w_{i} \text { and } l_{i} & =\text { initial specimen width and length, respectively } \\
m_{i} & =\text { initial specimen mass. }
\end{aligned}
$$




\subsection{RESULTS}

The glasses tested, a total of 16, at the SRTC for the initial VHT experiments were Hanford LAW productacceptance (HLP) glasses HLP-58 through -77. These glasses are part of a matrix of 75 glasses that were developed and tested with the aim to identify the relationship between glass composition and response to the PCT and VHT (Brown et al., 2000; Vienna et al., 2001). Also, these glasses were chosen for the initial VHT experiments at the SRTC since data already exists which could be used for comparison purposes, and glass bars were readily available. The glass bars used in this testing were fabricated at the SRTC.

\subsection{Alteration Rates}

For the purposes of this testing, the resistance of the glasses to corrosion in the VHT was measured at two temperatures $-175^{\circ} \mathrm{C}$ and $200^{\circ} \mathrm{C}$ (the latter being consistent with the current LAW specification). An example of a typical $m_{a}-t$ relationship observed in VHT is shown in Figure 2. The slope of the trendline of the $m_{a}-t$ relationship $\left(r=\mathrm{d} m_{a} / \mathrm{d} t\right)$ is the alteration rate of the glass, reported in $\mathrm{g} / \mathrm{m}^{2} / \mathrm{day}$. For this sample, and each glass tested at the SRTC, the rate was determined from only two data points. The VHT alteration rates measured at $200^{\circ} \mathrm{C}$ for each glass tested at the SRTC, as well as those reported by Vienna et al., 2001, are listed in Table 1. Also, $m_{a}-t$ relationship and experimental data for glasses tested in this study are reported in the Appendix.

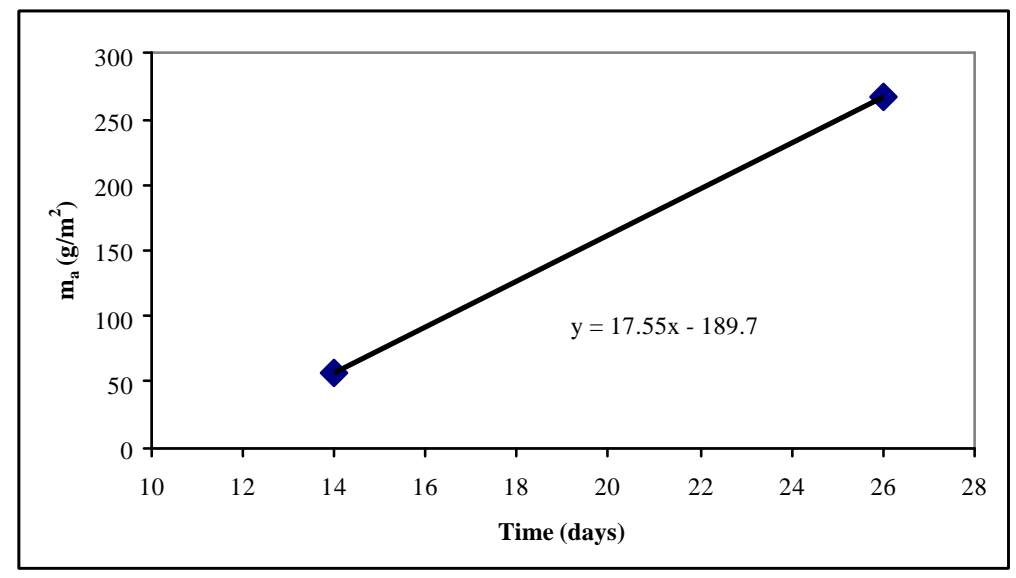

Figure 2. The $m_{a}$ as a Function of Time for HLP- 64 at $200^{\circ} \mathrm{C}$. 
Table 1. VHT Alteration Rates at $200^{\circ} \mathrm{C}$.

\begin{tabular}{|c|c|c|c|}
\hline \multirow[b]{2}{*}{ Glass ID } & \multicolumn{3}{|c|}{ Alteration Rate $\left(\mathrm{g} / \mathrm{m}^{2} /\right.$ day $)$} \\
\hline & SRTC testing $^{(1)}$ & PNNL data $(a)^{(1)}$ & PNNL data $(b)^{(2)}$ \\
\hline HLP-58 & 2.6 & 0.3 & 2.2 \\
\hline HLP-59 & 4.1 & 1.2 & 4.5 \\
\hline HLP-60 & 6.0 & 1.0 & 5.6 \\
\hline HLP-61 & 12.5 & 11.3 & 10.0 \\
\hline HLP-62 & 1.9 & -0.1 & 1.7 \\
\hline HLP-64 & 17.5 & 14.11 & 12.4 \\
\hline HLP-66 & --- & --- & 1336.9 \\
\hline HLP-67 & 205.8 & 11.3 & 230.5 \\
\hline HLP-68 & 13.6 & 11.8 & 5.7 \\
\hline HLP-69 & 4.0 & -0.3 & 3.8 \\
\hline HLP-71 & 14.7 & -58.5 & --- \\
\hline HLP-72 & 13.3 & 32.8 & 9.6 \\
\hline HLP-74 & 34.6 & 11.8 & 8.0 \\
\hline HLP-75 & 5.5 & 6.0 & 7.9 \\
\hline HLP-76 & --- & 3.6 & 140.9 \\
\hline HLP-77 & --- & -11.7 & 176.4 \\
\hline
\end{tabular}

The rates measured at $200^{\circ} \mathrm{C}$ at the SRTC were based on only two data points. The column labeled PNNL data (a) contains measured rates at similar time intervals as the SRTC testing. The column labeled PNNL data (b) is the full range of $200^{\circ} \mathrm{C}$ VHT data as reported in Vienna et al., 2001 (data points at $200^{\circ} \mathrm{C}$, but different time intervals). Alteration rates could not be determined for the HLP-66, -76, and -77 glasses during the SRTC testing. For the HLP-66 glass, the monolith was far too corroded (sample in broken pieces) to be cut and observed with the microscope for image analysis. Glasses HLP-76 and -77, which are compositionally the same as the LRM glass (Peeler et al., 1999), were tested twice at $200^{\circ} \mathrm{C}$ (no determination of slope as in Figure 2).

In comparing the rates determined at the SRTC with those of PNNL, most of the alteration rates show good agreement. There are few data points from these initial tests though, and the study is scoping in nature with the objective of establishing VHT capabilities. As stated by Vienna et al., 2001, the number and distribution of the measured data points influences the alteration rate, which can increase uncertainty. This is evidenced by the difference in the measured rates of PNNL data (a) and (b) (see Table 1). Also, higher temperatures enable specimens to fully react before a significant amount of water is lost, thus yielding more consistent and reproducible results.

\subsection{Specimen Cross-Section}

Specimen cross-sections were analyzed with the ocular microscope with motorized stage to measure the remaining glass thickness and to demonstrate the use and capabilities of the microscope. Selected samples (cross sections) are shown in Figures 3 through 8.

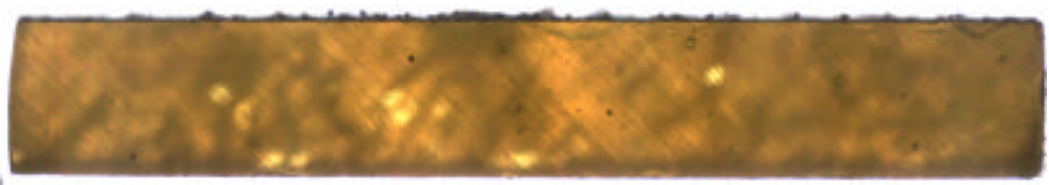

Figure 3. Cross-section of HLP-58 Subjected to VHT at $200^{\circ} \mathrm{C}$ for 26 Days. 


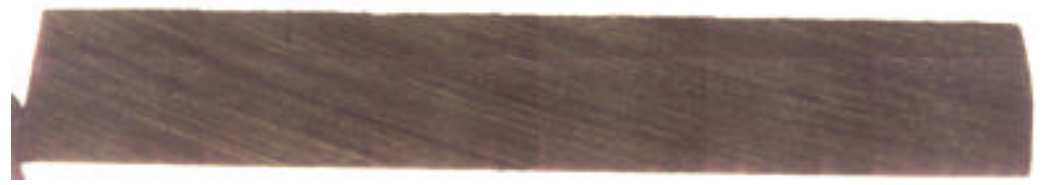

Figure 4. Cross-section of HLP-60 Subjected to VHT at $200^{\circ} \mathrm{C}$ for 26 Days.

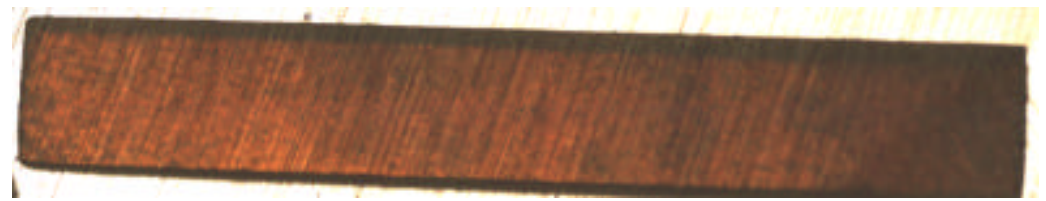

Figure 5. Cross-section of HLP-68 Subjected to VHT at $200^{\circ} \mathrm{C}$ for 26 Days.

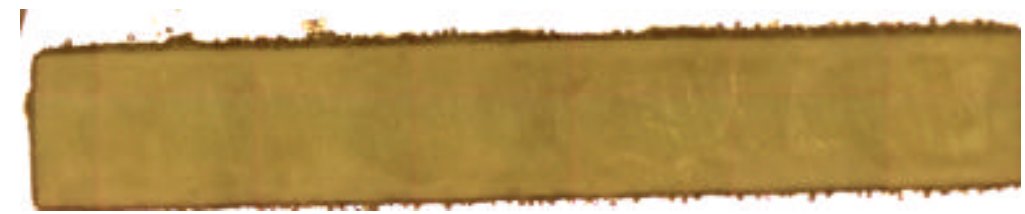

Figure 6. Cross-section of HLP-71 Subjected to VHT at $200^{\circ} \mathrm{C}$ for 26 Days.

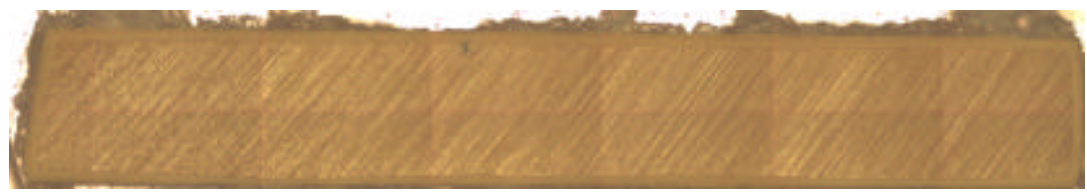

Figure 7. Cross-section of HLP-72 Subjected to VHT at $200^{\circ} \mathrm{C}$ for 26 Days.

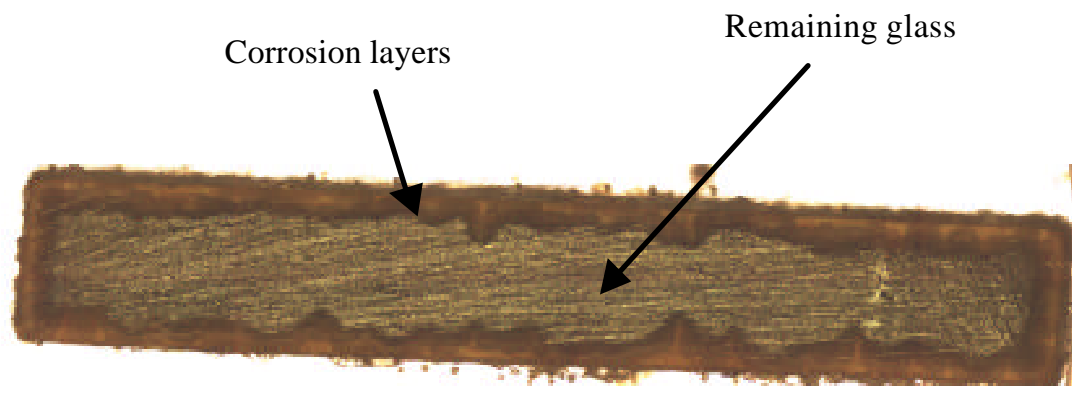

Figure 8. Cross-section of HLP-74 Subjected to VHT at $200^{\circ} \mathrm{C}$ for 26 Days.

These images of the sample's cross section show the remaining glass and the extent of the corrosion layers. For instance, the darker borders around the HLP-58 and HLP-61 cross sections (see Figures 5 and 6, respectively) represent the onset of the corrosion layers. The corrosion layers of HLP-74 were highly visible. The remaining glass is toward the center, but as indicated by its high $m_{a}$ value $\left(565.3 \mathrm{~g} / \mathrm{m}^{2}\right)$ and Figure 8, corrosion of this sample was quite progressed. These samples could have been sent for XRD and SEM analyses to identify the composition and phases of the alteration layers, but were not due to the number of samples and budgetary constraints. 


\subsection{CONCLUSIONS}

The VHT was performed at $175^{\circ} \mathrm{C}$ and $200^{\circ} \mathrm{C}$ on a suite of glasses for the purposes of this study. The main objective was to indicate that the SRTC could perform the VHT by the end of this scoping study. The SRTC has acquired all equipment necessary to perform the VHT, a technical procedure has been issued for the performance of the VHT, and it was demonstrated that the finished samples could be analyzed with the OM and IA. When compared with the alteration rate presented by Vienna et al., 2001, the data obtained at the SRTC is in close agreement (based on limited $200^{\circ} \mathrm{C}$ VHT data). Based on these demonstrations and observations, the SRTC now has the capabilities and capacities to perform the VHT if necessary.

\subsection{REFERENCES}

Brown, K.G., D.K. Peeler, J.C. Marra, J.D. Vienna, and A. Jiricka. 2000. Evaluation of the Testing Project in Support of Hanford Low-Activity Waste (LAW) Glass Product Acceptance, WSR-RP-200000280, Rev. 1, Westinghouse Savannah River Company, Aiken, South Carolina.

ITS Procedure Manual L29. 2002. Operation of Buehler Low-Speed Saw, ITS-0016, Rev. 0, Savannah River Technology Center, Westinghouse Savannah River Company, Aiken, South Carolina.

ITS Procedure Manual L29. 2002. Operation of Variable Low-Speed Grinder/Polisher, ITS-0017, Rev. 0, Savannah River Technology Center, Westinghouse Savannah River Company, Aiken, South Carolina.

ITS Procedure Manual L29. 2002. Vapor Hydration Tests, ITS-0019, Rev. 0, Savannah River Technology Center, Westinghouse Savannah River Company, Aiken, South Carolina.

Mann, F.M., K.C. Burgard, W.R. Root, R.J. Puigh, S.H. Finfrock, R. Khaleel, S.H. Bacon, E.J. Freeman, B.P. McGrail, S.K. Wurstner, and P.E. Lamont. 2001. Hanford Immobilized Low-Activity Waste Performance Assessment: 2001 Version, DOE/ORP-2000-24, Rev. 0, U.S. Department of Energy, Office of River Protection, Richland, Washington.

Peeler, D.K., A.D. Cozzi, D.R. Best, C.J. Coleman, and I.A. Reamer. 1999. Characterization of the Low Level Waste Reference Glass (LRM), WSRC-TR-99-00095, Westinghouse Savannah River Company, Aiken, South Carolina.

Schulz, R.L., T.H. Lorier, D.K. Peeler, K.G. Brown, I.A. Reamer, J.D. Vienna, A. Jiricka, B.M. Jorgensen, and D.E. Smith. 2000. Hanford Immobilized LAW Product Acceptance: Tanks Focus Area Testing Data Package II, PNNL-13344, Pacific Northwest National Laboratory, Richland, Washington.

U.S. Department of Energy (DOE). 2000. Design, Construction, and Commissioning of the Hanford Tank Waste Treatment and Immobilization Plant, Section C, Modification No. M008; DOE Office of River Protection, Richland, Washington 99352; Contract with Bechtel National, Inc., San Francisco, California 94105, Contract No. DE-AC27-01RV14136, issued August 31, 2000.

Vienna, J.D., A. Jiricka, B.P. McGrail, B.M. Jorgensen, D.E. Smith, B.R. Allen, J.C. Marra, D.K. Peeler, K.G. Brown, and I.A. Reamer. 2000. Hanford Immobilized LAW Product Acceptance: Initial Tanks Focus Area Testing Data Package, PNNL-13101, Pacific Northwest National Laboratory, Richland, Washington.

Vienna, J.D., P. Hrma, A. Jiricka, D.E. Smith, T.H. Lorier, I.A. Reamer, and R.L. Schulz. 2001. Hanford Immobilized LAW Product Acceptance Testing: Tanks Focus Area Results, PNNL-13744, Pacific Northwest National Laboratory, Richland, Washington. 
Westinghouse Savannah River Company

Savannah River Technology Center

Immobilization Technology Section

APPENDIX

VHT Data for HLP Glasses 
Westinghouse Savannah River Company

Savannah River Technology Center

Immobilization Technology Section

Table A.1. VHT Responses for VHT Glasses.

\begin{tabular}{|c|c|c|c|c|c|c|}
\hline Glass ID & $\mathrm{T}\left({ }^{\circ} \mathrm{C}\right)$ & $\mathrm{t}$ (days) & $\mathrm{H}_{2} \mathrm{O}$ added $(\mathrm{mL})$ & $\mathrm{H}_{2} \mathrm{O}$ lost $(\mathrm{mL})$ & $\mathrm{pH}$ Out & $m_{a}\left(g / m^{2}\right)$ \\
\hline HLP-58 & 200 & 14 & 0.30 & 0.03 & 9 & 32.8 \\
\hline HLP-58 & 200 & 26 & 0.30 & 0.05 & 10 & 63.8 \\
\hline HLP-58 & 175 & 40 & 0.21 & 0.03 & 10 & 104.5 \\
\hline HLP-59 & 200 & 14 & 0.30 & 0.03 & 10 & 25.6 \\
\hline HLP-59 & 200 & 26 & 0.30 & 0.05 & 10 & 74.2 \\
\hline HLP-59 & 175 & 40 & 0.21 & 0.02 & 11 & 87.3 \\
\hline HLP-60 & 200 & 14 & 0.30 & 0.03 & 8 & 32.8 \\
\hline HLP-60 & 200 & 26 & 0.30 & 0.05 & 8 & 104.9 \\
\hline HLP-60 & 175 & 40 & 0.21 & 0.02 & 8 & 98.3 \\
\hline HLP-61 & 200 & 14 & 0.30 & 0.03 & 10 & 58.8 \\
\hline HLP-61 & 200 & 26 & 0.30 & --- & --- & 208.6 \\
\hline HLP-61 & 175 & 40 & 0.21 & 0.13 & 9 & 215.9 \\
\hline HLP-62 & 200 & 14 & 0.30 & 0.03 & 7 & 4.1 \\
\hline HLP-62 & 200 & 26 & 0.30 & --- & --- & 26.9 \\
\hline HLP-62 & 175 & 40 & 0.21 & 0.02 & 8 & 49.5 \\
\hline HLP-64 & 200 & 14 & 0.30 & --- & --- & 56.0 \\
\hline HLP-64 & 200 & 26 & 0.30 & 0.06 & 8 & 266.6 \\
\hline HLP-64 & 175 & 40 & 0.21 & 0.03 & 9 & 456.2 \\
\hline HLP-66 & 200 & 14 & 0.30 & 0.03 & 11.5 & --- \\
\hline HLP-66 & 200 & 7 & 0.30 & --- & --- & -- \\
\hline HLP-66 & 175 & 7 & 0.21 & 0.01 & 11 & --- \\
\hline HLP-67 & 200 & 14 & 0.30 & 0.21 & 11 & 1457.3 \\
\hline HLP-67 & 200 & 7 & 0.30 & 0.03 & 8.5 & 16.5 \\
\hline HLP-67 & 175 & 14 & 0.21 & 0.03 & 10 & 2008.3 \\
\hline HLP-68 & 200 & 14 & 0.30 & 0.04 & 11 & 121.3 \\
\hline HLP-68 & 200 & 26 & 0.30 & --- & -- & 284.4 \\
\hline HLP-68 & 175 & 40 & 0.21 & 0.03 & 11 & 150.4 \\
\hline HLP-69 & 200 & 14 & 0.30 & 0.04 & 7 & 150.8 \\
\hline HLP-69 & 200 & 26 & 0.30 & 0.14 & 8 & 198.3 \\
\hline HLP-69 & 175 & 40 & 0.21 & 0.03 & 6 & 101.6 \\
\hline HLP-71 & 200 & 14 & 0.30 & 0.03 & 11 & 124.6 \\
\hline HLP-71 & 200 & 26 & 0.30 & 0.06 & 10 & 301.5 \\
\hline HLP-71 & 175 & 40 & 0.21 & 0.01 & 11 & 255.3 \\
\hline HLP-72 & 200 & 14 & 0.30 & 0.04 & 8 & 167.2 \\
\hline HLP-72 & 200 & 26 & 0.30 & 0.04 & 10 & 327.1 \\
\hline HLP-72 & 175 & 40 & 0.21 & 0.02 & 10 & 495.6 \\
\hline HLP-74 & 200 & 14 & 0.30 & 0.02 & 10 & 150.3 \\
\hline HLP-74 & 200 & 26 & 0.30 & 0.05 & 10 & 565.3 \\
\hline HLP-74 & 175 & 40 & 0.21 & 0.02 & 10 & 718.2 \\
\hline HLP-75 & 200 & 14 & 0.30 & 0.03 & 11 & 340.1 \\
\hline HLP-75 & 200 & 26 & 0.30 & --- & --- & 406.2 \\
\hline HLP-75 & 175 & 40 & 0.21 & 0.02 & 11 & 461.9 \\
\hline HLP-76 & 200 & 14 & 0.30 & 0.03 & 11 & 1824.3 \\
\hline HLP-76 & 200 & 14 & 0.30 & 0.04 & 10 & 1783.6 \\
\hline HLP-76 & 175 & 21 & 0.21 & 0.02 & 8 & 1608.6 \\
\hline HLP-77 & 200 & 14 & 0.30 & 0.05 & 10 & 1898.2 \\
\hline HLP-77 & 200 & 14 & 0.30 & 0.03 & 10 & 1901.4 \\
\hline HLP-77 & 175 & 21 & 0.21 & 0.02 & 10 & 1857.3 \\
\hline
\end{tabular}

